\title{
Prejudice in Past Pandemics
}

\author{
Sarah Bahsoun \\ University of Florida
}

Faculty Mentor: Anne Donnelly, Center for Undergraduate Research

\begin{abstract}
Accompanying the spread of SARS-CoV-2 (COVID-19) across the globe was a proliferation of antiAsian hate crimes and political rhetoric. These discriminatory actions mirrored the prejudice exhibited towards other groups in past pandemics, such as Jewish populations in Europe during the Black Death (1346). This study aimed to determine similar patterns relating to and underlying the prejudice seen in three of history's most devastating pandemics, focusing on three categories: hate crimes, political rhetoric, and religiosity during the Black Death (1346), 1918 Flu and COVID-19 pandemics. Prejudice against Jewish people during the Black Death, Immigrants in America during the $1918 \mathrm{Flu}$, and Asian Americans during COVID-19 were investigated in this study because of the extensive historical record of existing prejudice against these groups before the pandemics and the broad geographical range the prejudice occupied. Both qualitative and quantitative data from existing reviews, primary source databases, and crime reports were compiled and compared to determine that overall, there was no general pattern of hate crimes during past pandemics without accompanying political rhetoric. In addition, there was no general pattern relating to religion in the pandemics studied, suggesting that the prejudice was not fueled by religious motivations. Given the small selection of pandemics analyzed in this study, further analysis with more pandemics could present more robust conclusions.
\end{abstract}

Keywords: prejudice, Black Death, Spanish Flu, COVID-19, pandemics

\section{Introduction}

In early spring of 2020, the SARS-CoV-2 (COVID-19) pandemic brought global activities to a screeching halt. To contain the spread of the highly contagious respiratory virus, countries worldwide initiated lockdowns of schools, travel, and non-essential businesses. These lockdowns had a series of cascading negative effects on the world economy, contributing to an international rise in unemployment and a global recession (ILO, 2020). Many individuals exasperated with the negative effects of the pandemic began directing their frustrations towards persons of Asian descent, citing the believed origin of the virus in Wuhan, China. The present time of writing marks one year after the World Health Organization declared COVID-19 a pandemic in March 2020 (WHO, 2020), and since then, violence against members of the Asian community has 
markedly increased, most notably in the United States (CSHE, 2021). Unfortunately, this violence against the Asian-American community closely mirrors the violence exhibited against Jewish communities in Europe during the Black Death (1346-1353), where thousands of Jewish communities were decimated (Zentner, 2015). In both scenarios, there was existing evidence of prejudice against these groups before the pandemics began, and the prejudice appeared to increase accompanying the spread of disease (See Figure 1).

(A)

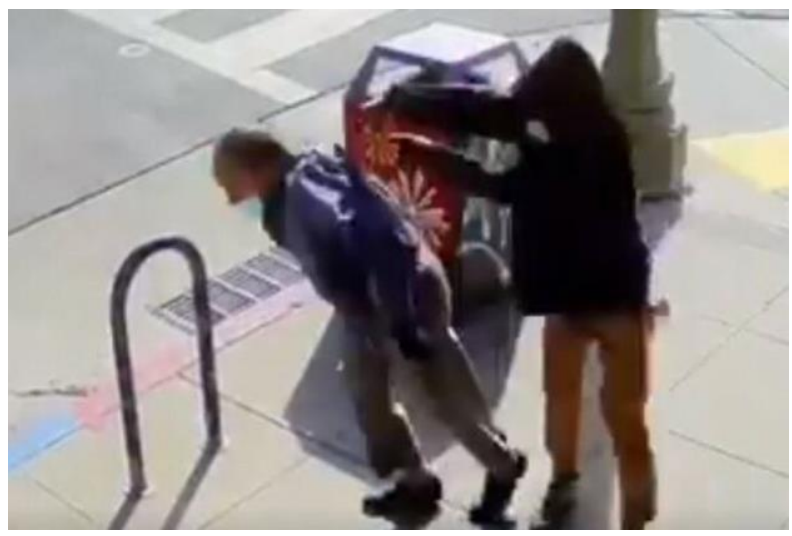

(B)

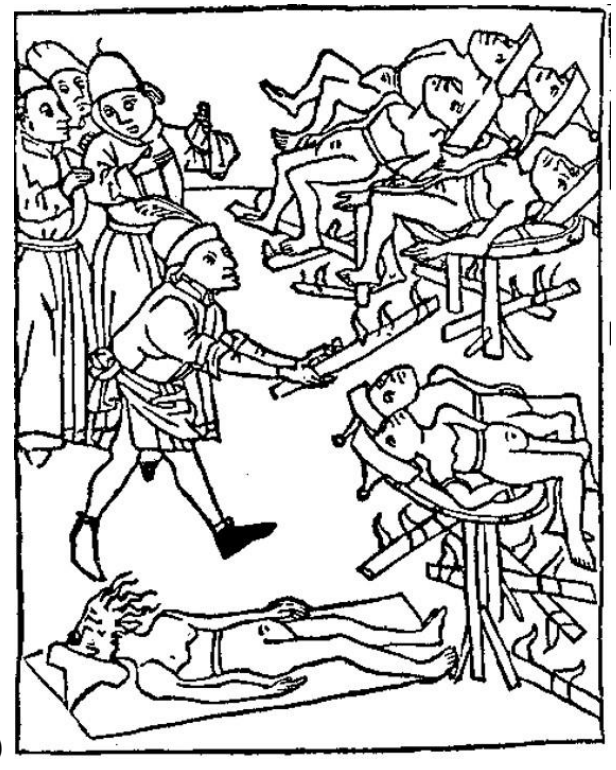

Figure 1. (A) January $31^{\text {st }}, 2021$, a 28-year-old man seen assaulting a 91-year-old Asian American in Oakland, California (Magnier \& Churchill, 2021). (B) A woodcut from 1475 depicts Jewish persons being tortured and burned in relation to the proliferation of the Black Death (Hess, 2020). Both images depict only a few examples of the violent hate crimes transcending across the centuries during pandemics. 
This study aimed to determine similar patterns relating to and underlying these prejudicedriven actions observed in past pandemics to provide a greater understanding surrounding the relationship between existing prejudice against particular groups and how that relationship changes during a pandemic. Three major pandemics with the greatest abundance of literature and existing evidence of prior prejudice prior were selected for this analysis: The Black Death (1346 to 1353), The Influenza of 1918 (1918 to 1920), and the COVID-19 Pandemic (2019 to current). The three patterns selected for investigation were hate crimes, political rhetoric, and religiosity; each chosen based on the availability of existing literature and because each are elements of society that have transcended across the centuries between each pandemic. Please see Table 1 for specific definitions of each pattern.

Table 1. The selected definitions of the patterns investigated in this study.

\begin{tabular}{|l|l|}
\hline Pattern & Description \\
\hline Hate Crimes & $\begin{array}{l}\text { Hate crimes as defined by the FBI are } \\
\text { "criminal offense against a person or property } \\
\text { motivated in whole or in part by an offender's } \\
\text { bias against a race, religion, disability, sexual } \\
\text { orientation, ethnicity, gender, or gender } \\
\text { identity" (FBI, 2016). }\end{array}$ \\
\hline Political Rhetoric & $\begin{array}{l}\text { Political rhetoric in this study is categorized } \\
\text { as both politics expressed by rhetoric and } \\
\text { rhetoric delivered by way of politics. }\end{array}$ \\
\hline Religiosity & $\begin{array}{l}\text { In this study, religiosity is defined as "the } \\
\text { quality or state of being religious" (Merriam- } \\
\text { Webster, 2021). }\end{array}$ \\
\hline
\end{tabular}

Each society, be it Medieval Europe or the modern United States, contains record of hate crimes, political rhetoric, and religion. Although their manifestations may differ with the advent of technology, evidence of their existence nonetheless exists and demonstrates how humans behave in similarly even across the centuries.

Information on prejudice occurring during The Black Death and The Influenza of 1918 was obtained primarily through existing literature reviews, qualitative historical analyses, and primary source databases. Data concerning COVID-19 prejudice was obtained largely through criminal reports with quantitative data. 


\section{Background}

\section{The Black Death (1346 to 1353)}

The Black Death was one of Europe's most devastating diseases, estimated to have killed at least 50 million people in Europe alone (Benedictow, 2005). Believed to have been caused by the bacterium Yersinia pestis, the Black Death first entered Europe through trade routes from Central Asia. As the Black Death spread across Europe, the number of hate crimes against Jewish communities also increased, likely because of the disease. Unfortunately, this was only a continuation of a long history of hate crimes against Jewish populations across Europe. Ultimately, both hate crimes and negative political rhetoric against Jewish populations increased with the arrival of the pandemic.

\section{Hate Crimes}

Early evidence of hate crimes against Jewish communities extends to the Roman Empire (Wagemakers, 2010). Judeo-Christian followers were generally persecuted under Roman rule until Emperor Constantine issued the Edict of Milan in $312 \mathrm{AD}$, facilitating greater tolerance of Judaism and Christianity (Closs, 2013). Yet, while Christianity united the European continent as the Western Roman Empire fell in 476 AD, followers of Judaism continued to experience persecution. In the decades preceding the arrival of the Black Death in 1346, anti-Semitic hate crimes and political rhetoric were on the rise in Germany, fueled by a group called the Judenschächter, which translates to "those who slaughtered Jews" (Winkler, 2005). These anti-

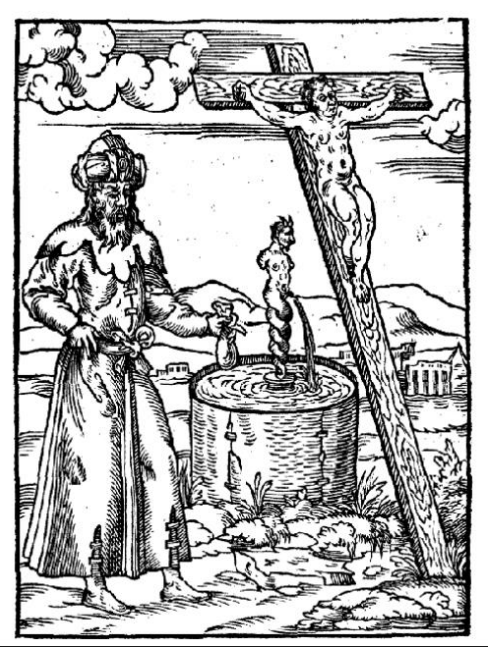

Figure 2. A $14^{\text {th }}$ century French woodcut intended to depict a Jewish person poisoning a well (Luborsky, 1995). 
Semitic hate crimes sharply increased as the Black Death entered Europe. Pogroms, also known as organized massacres, against Jewish people proliferated across Europe, with most massacres occurring against Jewish communities in France, Spain, and Germany (Cohn, 2012). As the Black Death ravaged the European continent, rumors began circulating that Jewish people were poisoning local water sources and food (See Figure 2). Historians attribute these rumors to the differences in cleanliness rituals between Jewish and Christian peoples at that time. For example, many Jewish people did not use water from the common wells of towns, believing them to be unclean (Zahler, 2009). Avoiding these communal water sources decreased transmission of the Black Death and led to fewer deaths in Jewish communities. However, these lower mortality rates only fueled the fervor against Jewish communities, and throughout the Black Death, Jewish communities were targeted and killed en mass (Winkler, 2005).

\section{Political Rhetoric}

Accompanying the long history of hate crimes against Jewish populations in Europe is the long history of anti-Semitic political rhetoric. In the decades preceding the Black Death, many Jewish immigrants came to Europe as merchants, accumulating wealth but also distrust among their native European neighbors. Nonetheless, accumulation of wealth was not necessarily the source of anti-Semitic political rhetoric, as European monarchies benefitted from favorable relationships with wealthy Jewish merchants (Zentner, 2015). However, during the Black Death, the actions of the newly ascended emperor to the throne of the Holy Roman Empire, Charles IV, reversed this relationship. In 1347, then Emperor Louis IV died in a hunting accident, prompting the throne of the Holy Roman Empire to be seized by Charles IV (Winkler, 2005). While the German throne was historically favorable to Jewish merchants who controlled much of the wealth in the kingdom, Charles IV was preoccupied with securing this newly acquired position (Thomson, 1950). He decided not to protect Jewish communities in his empire and declared that property stolen from Jewish people did not have to be returned (Heinz, 1983). This declaration legitimized the hate crimes and allowed them to continue.

Negative political rhetoric surrounding Jewish populations also began from sources associated with The Catholic Church, then the most powerful institution in Europe. During the Black Death, the political rhetoric of Pope Clement VI has been subject to varying interpretations. His Sicut Judeis papal bull (a public statement), presented on July $5^{\text {th }}, 1348$, has been met with both praise and skepticism by historians (Zahler, 2009). While this papal bull was 
meant to protect Jewish people from hate crimes during the Black Death, the Pope's statements were released more than one year after the most catastrophic massacres had occurred (Winkler, 2005). Other sources even suggest that political rhetoric by Christian local governments was deliberately orchestrated to encourage pogroms against Jewish communities (Ritzmann, 1998).

\section{Religiosity}

Historians have suggested that Christian leaders may have encouraged anti-Semitism in the wake of a growing decline of faith in the Church (Winkler, 2005). Prior to the Black Death, Europeans during the Middle Ages turned towards the Church for advice. Note that during the Black Death (1346 to 1353) the Protestant Reformation had not yet occurred, so all Christians mentioned in this section are followers of Catholicism and looked to the Church for guidance. However, as the Church focused on accumulating wealth and political power, its followers began to increasingly distrust the institution (Zentner, 2015). In addition, as the mortality rate of the clerical population increased during the Black Death, more individuals lost faith in the Church, as the Church had at one point insisted that the Black Death selectively infected sinners (Herlihy, 1997). There was a documented wave of religious fervor over Ars moriendi, a traditional series of rituals to ensure passage into Heaven after death. During the Black Death such rituals were disrupted, especially because a clergy heavily depleted in numbers struggled to reach everyone in their communities (Lehfeldt, 2004). This contributed to the overall decline in faith in the clergy. Nonetheless, decline of faith in the institution of The Church does not equate to decreased religiosity, of which there was no consistent evidence found.

\section{The Influenza Pandemic of 1918 (1918 to 1920)}

As COVID-19 spread across the United States, many compared the virus to the Influenza pandemic between 1918 and 1920, commonly known as the "Spanish Flu." This influenza infected an estimated 500 million people and killed between 20 and 50 million worldwide, nearly reaching the catastrophic numbers of the Black Death (Noel, 2020). While the flu was first reported by Spanish news outlets, thus garnering the name "Spanish Flu," the first reported cases occurred in the state of Kansas. 


\section{Hate Crimes}

In the decades leading up to the $1918 \mathrm{Flu}$, the United States experienced its heaviest era of immigration (Jaret, 1999). In his article on Anti-Immigration Attitudes during 1880 and 1924, Jaret notes that in 1880, when the immigration surge began, Americans were relatively friendly and open to foreigners provided they were not Chinese (See Figure 3). However, by 1921 Americans had begun to distinguish between "old immigrants" (from Northern and Western Europe) and "new immigrants" (from Southern and Eastern Europe and Asians) and heavily supported restrictive immigration laws against "new immigrants" until 1924 (Jaret, 1999). Yet, both during and after the pandemic in 1918, there was no consistent evidence found of hate crimes against immigrants attributed to the pandemic itself. Rather, evidence of prejudice against immigrants manifested largely in the form of anti-immigration political legislature rather than through violent actions. However, this lack of evidence could be attributed to the limited data availability of crimes during this period. Ultimately, further investigation of primary source material is required.

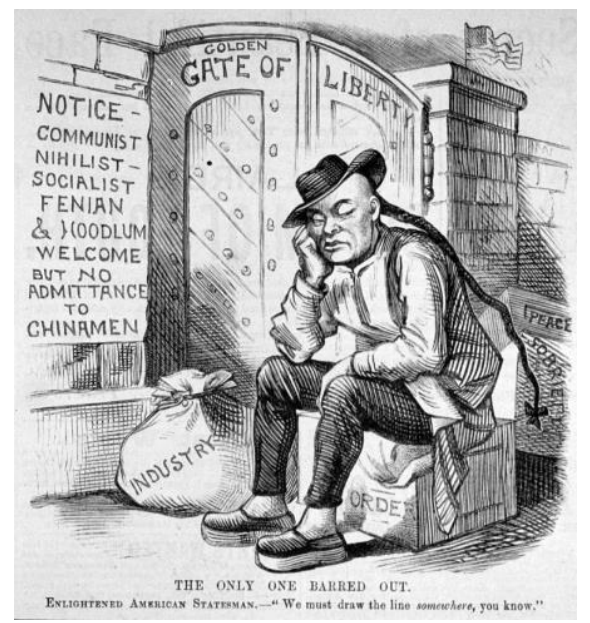

Figure 3. A political cartoon demonstrating how even as immigrants were generally accepted in the United States, Chinese immigrants were discriminated against as early as 1882. Source: Bill of Rights Institute

\section{Political Rhetoric}

Anti-immigration legislature targeted "new immigrants" and particularly Asian immigrants beginning with the 1882 Chinese Exclusion Act, which barred the entry of Chinese immigrants into America. Decades later, the Immigration Act of 1917 halted immigration from other Asian countries excluding the Philippines (Jaret, 1999). American Congress even sought to "scientifically" justify their actions, authorizing the Dillingham Commission to conduct an official investigation (Benton-Cohen, 2018). This commission resulted in a nationwide halt in 
immigration in 1924, which was not reinstated until 1965 (Benton-Cohen, 2018). Despite the passing of this discriminatory and notably bipartisan legislature, there was no evidence of widespread anti-Immigrant political rhetoric during the Influenza pandemic. During this time, most political rhetoric was focused on the war effort (See Figure 4), with President Woodrow Wilson's administration staying relatively silent about the pandemic (Troy, 2020). Notably, the United States government appeared to downplay the severity of the virus, printing in an official pamphlet that "ordinarily, the fever lasts from three to four days and the patient recovers" (Blue, 1918) even as the mortality rates were rising (CDC, 2019).

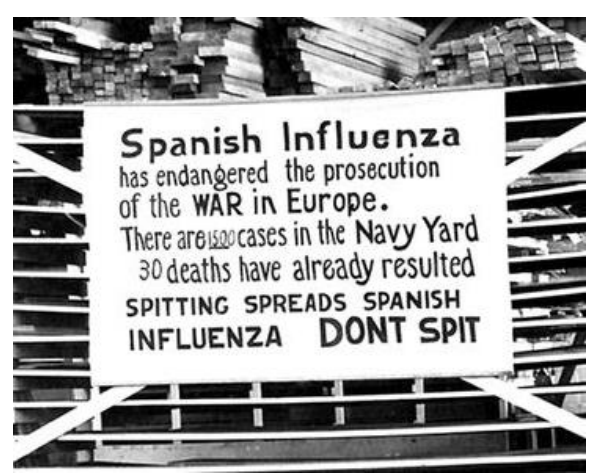

Figure 4. A sign demonstrating how even as the pandemic raged on, the United States was still intently focused on the war effort and any rhetoric about the flu referenced the ongoing war. Source: Smithsonian Magazine

\section{Religiosity}

In the late $20^{\text {th }}$ century, religion as a nationwide source of unification was slowly on the decline in western Europe and the United States (Phillips, 2020). Despite this, religion remained a uniting force within smaller communities. For example, during the $1918 \mathrm{Flu}$, leaders of Jewish communities rallied in major cities including San Francisco and New York City to inform their communities on how to avoid the flu in 1918 (Cohn, 2012). Even in Zamora, Spain, inhabitants continued to congregate in Churches during the flu and consequently observed among the highest mortality rates reported in Spain (Trilla et al., 2008). These individuals described having lost faith in science but found their faith rejuvenated by practicing their faith with their neighbors, despite the mortalities. There was no widespread or consistent evidence of this found in the United States. 


\section{The COVID-19 Pandemic (January 2019 to current)}

Unlike the past two pandemics, COVID-19 emerged when society had unprecedented access to technology. These technological advantages undoubtedly prevented the death toll from reaching otherwise higher levels but may have easier facilitated the spread of prejudice through social media networks. This study focuses on the prejudice exhibited against Asian Americans in the United States because of the large volume of data available on hate crimes and political rhetoric.

\section{Hate Crimes}

During the COVID-19 pandemic, hate crimes against Asian Americans sharply increased. A report released by the Center for the Study of Hate and Extremism documented a surge in AntiAsian hate crimes by $145 \%$ in 16 of America's largest cities, while the rate for overall hate crimes dropped by 6\% (CSHE, 2021). Unfortunately, Asian Americans are also less likely to report hate crimes (Chun, 2020), suggesting the number of recounted crimes in this report is underestimated. This sharp rise in attacks against Asian Americans only occurred after the outbreak of coronavirus in the spring of 2020, suggesting that the hate crimes was directly linked with the onset of the pandemic (CSHE, 2021). At this time of writing, the pandemic remains at large, so no information on hate crimes after the pandemic can be discussed.

\section{Political Rhetoric}

Like the transition of power in the Holy Roman Empire during The Black Death, the United States witnessed its own power exchange during COVID-19, leading up to and following the 2020 Presidential election. Throughout 2020, Democratic and Republican politicians faced intense scrutiny as their presidential candidates battled for the nation's highest office. Social media, notably Twitter, became a major platform where lawmakers communicated with their constituents, and where political rhetoric associated with the pandemic could be observed. A study conducted by the group Stop AAPI Hate investigated anti-Asian American rhetoric by politicians on Twitter in the months leading up to the 2020 presidential election and found that the tweets with anti-Asian rhetoric demonstrably reached millions of individuals across the country who agreed with the sentiments (demonstrated by a "like" or "retweet"). This affirmed a spread of anti-Asian political rhetoric in relation to the pandemic (Note: Please see the full report for a more detailed breakdown of the political rhetoric) (Chun, 2020). This report also found that former President Donald Trump was the most prolific of all politicians in expressing anti-Asian 
sentiments on Twitter; at least 24 tweets using stigmatizing rhetoric garnering more than 4,276,200 total likes (Chun, 2020).

\section{Religion}

Organized religion garnered attention in America after some states attempted to halt religious congregations to mitigate the spread of the virus. Nevertheless, there was no significant change of religiosity among many Americans and Europeans. The Pew Research Center conducted a survey of almost 15,000 adults across America to survey if the pandemic had strengthened their religious faith. Among those who were religious, 28\% of Americans reported experiencing an increase in their religiosity, or their faith, as a result of the pandemic (Pew Research Center, 2021). However, this not a majority, suggesting that religious faith did not drastically change because of the pandemic and is therefore not linked to the prejudice.

\section{Results}

While limited in number, the three selected pandemics provided ample evidence for an investigation of three potential patterns: hate crimes, political rhetoric, and religiosity. Concerning hate crimes, there was an overwhelming amount of evidence demonstrating hate crimes against Jewish populations in Europe increased along with the onset of the Black Death. Similarly, reports of hate crime statistics against Asian Americans in the United States also demonstrated a rise in hate crimes along with the COVID-19 pandemic. However, while evidence of prejudice against immigrants in America existed decades before the 1918 Flu, there was no consistent evidence of hate crimes against immigrants in association with the pandemic.

In both the Black Death and COVID-19 pandemics, prejudice and hate crimes against Jewish people and Asian Americans respectively were documented before the pandemic, but further evidence is needed to determine a pattern in hate crimes after the pandemic. These two pandemics also exhibited a similarity in political rhetoric in association with the pandemics, as political leaders during both pandemics either ignored or indirectly encouraged the hate crimes through inflammatory political rhetoric, thereby allowing the crimes to proliferate. However, during the 1918 Influenza pandemic, there was no consistent evidence that anti-Immigrant political rhetoric was advanced in relation to the pandemic, as most of the political rhetoric was focused on World War I. This absence of political rhetoric during the Influenza of 1918 could potentially explain the lack of hate crimes and imply that hate crimes occur only when fueled by political rhetoric. Thus, a potential pattern emerges as both political rhetoric and hate crimes 
were observed during the Black Death and COVID-19 pandemics, while the lack of political rhetoric during the 1918 Influenza explains the lack of hate crimes (See Figure 5).

Finally, there was no general pattern of changes in religiosity in association with the pandemic. While the Black Death demonstrated a clear decline in faith in The Church, this could

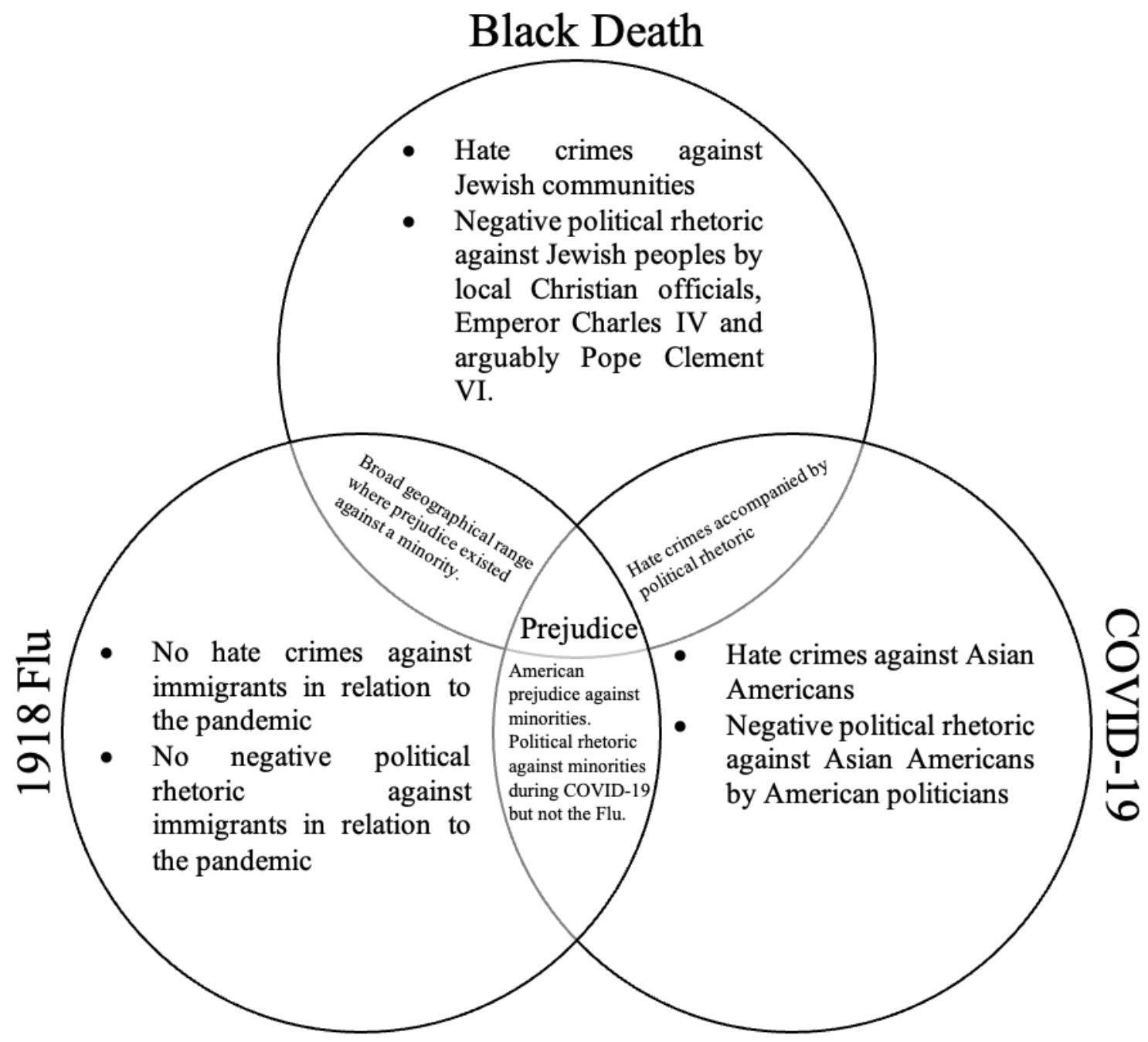

Figure 5. A visual depiction of the results.

be interpreted as a decline of faith in the institution rather than religion itself. This could potentially mirror the growing acts of violence against the institution of the American government during the COVID-19 pandemic; however, this is outside the scope of this research project. Ultimately, there is insufficient evidence to suggest prejudiced actions observed in each of the pandemics were religiously motivated. 


\section{Conclusion}

Between the three examples discussed, the results suggest that during a pandemic, widespread hate crimes largely occur when accompanied by political rhetoric. In addition, religious faith appeared to have no association with a pandemic, suggesting that the hate crimes themselves against people belonging to certain religious groups were not religiously motivated. This study attempted briefly survey and piece together evidence from three different pandemics dating back hundreds of years to assess the factors underlying the prejudice that continues to occur even through the centuries. Between the Black Death and COVID-19 pandemics is nearly a 700-year gap. Yet, while countries, religions, and societal norms have evolved, prejudice remains as prolific as ever. To understand why, future research could investigate a larger sample size of pandemics to generate more robust patterns, and determine why after hundreds of years, prejudice continues to occur along a time when populations are already needlessly suffering.

\section{Acknowledgements}

Thank you to Ami Patel, Anjali Patel, Jennifer Moses and Dr. Anne Donnelly for their unwavering help and support during this project.

\section{References}

Benedictow, O. (2005). The Black Death: The Greatest Catastrophe Ever. History Today, 55(3). https://www.historytoday.com/archive/black-death-greatest-catastrophe-ever

Benton-Cohen, K. (2018). Inventing the Immigration Problem: The Dillingham Commission and Its Legacy. Boston: Harvard University Press

Bill of Rights Institute (2020). Gilded Age Immigration Cartoons. https://billofrightsinstitute.org/e-lessons/gilded-age-immigration-cartoons

Blue, R. (1918). United States Public Health Service: Spanish Influenza. https://id.lib.harvard.edu/curiosity/contagion/36-990068058060203941.

Centers for Disease Control and Prevention (CDC). (2019). 1918 pandemic. https://www.cdc.gov/flu/pandemic-resources/1918-pandemic-h1n1.html.

Center for Study of Hate and Extremism (CSHE). (2021). Anti-Asian Hate Crime Reported to Police in America's Largest Cities : 2019 \& 2020. [Report] https://www.csusb.edu/sites/default/files/FACT SHEET- Anti-Asian Hate 2020 rev 3.21.21.pdf

Chun, C. (2020). The return of the 'Yellow Peril.' Language, Culture and Society, 2(2), 252- 
259. https://doi.org/10.1075/lcs.00029.chu

Closs, V. (2013). While Rome Burned: Fire, Leadership, and Urban Disaster in the Roman Cultural Imagination.

http://repository.upenn.edu/edissertations\%0Ahttp://repository.upenn.edu/edissertations/844

Cohn, S. (2012). Pandemics: waves of disease, waves of hate from the Plague of Athens to A.I.D.S.. Hist. J., 85, 535-555. https://doi.org/10.1111/j.14682281.2012.00603.x.Pandemics

FBI. (2016). Hate crimes. FBI. https://www.fbi.gov/investigate/civil-rights/hate-crimes.

Heinz, T. (1983). Deutsche Geschinechte des Spatmittelalters 1250-1500 . Stuttgart: W. Kohlhammer

Herlihy, D. The Black Death and the Transformation of the West. Cambridge: Harvard University Press, 1997.

Hess, P. (2020, March 20). Contagion: Trump's Harmful Blame Game. Cultures contexts. https://sites.utexas.edu/culturescontexts/2020/03/.

ILO. (2020). ILO Monitor: COVID-19 and the world of work. Second edition. Updated estimates and analysis. International Labour Organization.

https://www.ilo.org/wcmsp5/groups/public/@dgreports/@dcomm/documents/briefingnote/ wcms_740877.pdf

Jaret, C. (1999). Troubled by Newcomers: Anti-Immigrant Attitudes and Action during Two Eras of Mass Immigration to the United States. Journal of American Ethnic History, 18(3), 9-39. http://www.jstor.org/stable/27502448

Lehfeldt, E. The Black Death (Problems in European Civilization). Boston: Houghton Mifflin, 2004

Luborsky, R. (1995) The Pictorial Image of the Jew in Elizabethan Secular Books, Shakespeare Quarterly, 46(4), 449-453, https://doi.org/10.2307/2870982

Magnier, M., \& Churchill, O. (2021). Greater Asian-American representation needed to stem hate. South China Morning Post.

https://www.scmp.com/news/china/article/3121518/greater-asian-american-representationleadership-ranks-needed-stem-

hate?module=perpetual_scroll\&pgtype=article\&campaign $=3121518$.

Merriam-Webster. (n.d.). Pogrom. https://www.merriam-webster.com/dictionary/pogrom.

Merriam-Webster. (n.d.). Religiosity. https://www.merriam-webster.com/dictionary/religiosity.

Noel, T. (2020). Conflating culture with COVID-19 : Xenophobic repercussions of a global pandemic. Social Sciences and Humanities Open 2, January. https://doi.org/10.1016/j.ssaho.2020.100044 
Pew Research Center. (2021). More Americans Than People in Other Advanced Economies Say COVID-19 Has Strengthened Religious Faith.

https://www.pewforum.org/2021/01/27/more-americans-than-people-in-other-advancedeconomies-say-covid-19-has-strengthened-religious-faith/

Phillips, H. (2020). '17, '18, '19: Religion and science in three pandemics, 1817, 1918, and 2019. Journal of Global History, 15(3), 434-443. https://doi.org/10.1017/S1740022820000315

Ritzmann, I. (1998). The Black Death as a cause of the massacres of Jews: a myth of medical history? Medizin, 17, 101-10130. https://pubmed.ncbi.nlm.nih.gov/11625662/

Smithsonian Institute. (2018). Philadelphia Threw a WWI Parade That Gave Thousands of Onlookers the Flu [Image]. https://www.smithsonianmag.com/history/philadelphia-threwwwi-parade-gave-thousands-onlookers-flu-180970372/

Thomson, S. (1950). Learning at the Court of Charles IV. Speculum, 25(1), 1-20. https://www.jstor.org/stable/i332899

Trilla, A., Trilla, G. \& Daer, C. (2008). The 1918 "Spanish Flu” in Spain, Clinical Infectious Diseases, 47(5), 668-673. https://doi.org/10.1086/590567

Troy, T. (2020). Shall We Wake the President? Two Centuries of Disaster Management from the Oval Office. Guilford: Lyons Press

WHO. (2020). WHO director-general's opening remarks at the media briefing on COVID-19 - 11 March 2020. https://www.who.int/director-general/speeches/detail/who-director-general-sopening-remarks-at-the-media-briefing-on-covid-19---11-march-2020

Winkler, A. (2005). The Medieval Holocaust: the approach of the plague and the destruction of Jews in Germany, 1348-1349. Federation of East European Family History Societies, 8, 624. http://hdl.lib.buy.edu/1877/3770

Zahler, D. (2009). The Black Death. Minneapolis: Twenty-First Century Books.

Zentner, M. (2015). The Black Death and its Impact on the Church and Popular Religion. University of Mississippi, 1-67.

http://publicacoes.cardiol.br/portal/ijcs/portugues/2018/v3103/pdf/3103009.pdf\%0Ahttp://w ww.scielo.org.co/scielo.php?script=sci_arttext\&pid=S0121-

75772018000200067\&lng=en\&tlng=en\&SID=5BQIj3a2MLaWUV4OizE\%0Ahttp://scielo.i ec.pa.gov.br/scielo.php?script=sci_ 